\title{
Knowledge and Attitude of Cervical Cancer Screening and its Prophylactic Vaccination Against Human Papillomavirus Among the Undergraduate Medical Students in a Tertiary Care Hospital
}

\author{
Ramya Gandhi ${ }^{1}$, Nitya Selvaraj ${ }^{2 *}$, Ilamparithi Janarthanan ${ }^{3}$ \\ ${ }^{1}$ Department of Pathology, Sri Manakula Vinayagar Medical College and Hospital, Puducherry, India \\ ${ }^{2}$ Department of Pharmacology, Sri Manakula Vinayagar Medical College and Hospital, Puducherry, India \\ ${ }^{3}$ Sri Manakula Vinayagar Medical College and Hospital, Puducherry, Indial
}

\begin{abstract}
Background: Cervical cancer is the second most common malignancy in females and Human papilloma virus[HPV] is the main etiological factor of cervical cancer and it is an important public health issues. The aim of this study is to assess the level of awareness and attitude towards cervical cancer screening and its prophylactic HPV vaccination amongst the undergraduate medical students.

Methods: It is a cross sectional study and it was conducted by the Department of Pathology and Pharmacology at Sri Manakula Vinayagar Medical College and hospital ,Puducherry in south India by involving the M.B.B.S undergraduate students from July 2017 to August 2017. Totally 400 students were consented from second year to final year for this study ,a validated and pre-tested questionnaires were filled by them .

Result: It was observed that majority of the participants were in the age group of 20- 21 and male participants (50.3\%) were higher than female participants ( $49.7 \%)$. Majority of the participants were from 5th semester(41.5\%), 7th semester(26.5\%), 9th semester $(25.8 \%)$ compared to the 6th and 8th semester. $96.8 \%$ of the participants showed positive attitude about their knowledge on cervical cancer and $91.5 \%$ regarding pap smear and $55 \%$ for HPV vaccination. Very few students $7 \%$ had already taken vaccine with no significant differences between the various semesters of medical students.

Conclusion: In conclusion the Knowledge and attitude of the participants were positive and high .But only few students had vaccination. Thus ,more knowledge about cervical cancer, pap smear screening and HPV vaccination campaign services can be provided among the medical students.
\end{abstract}

Keywords: Cervical Cancer, pap Smear, HPV Vaccination.

\section{Introduction}

Cervical cancer is the second most common malignancy in females and it is important public health issues and it is the commonest malignancy among women in India. ${ }^{[1]}$ High risk strains of 16 and 18 of human papilloma virus [ HPV] is the most common sexually transmitted disease which is responsible for all precancerous, dysplastic and invasive cervical cancers and it is documented that smoking and family history can also be a causative of cervical cancer. [2,3] Primary screening like pap smear test for HPV infections in cervix is a simple, non- invasive technique for early detection of in situ to invasive carcinoma. ${ }^{[4]}$. And the development of HPV vaccines such as the bivalent vaccine for HPV types 16 and18; and the quadrivalent vaccine for HPV types 16 and 18 acts as a preventive and also aids protection for controlling this disease ${ }^{[2,3]}$. Being the most effective and newly developed concept of preventing the cancer cervix by early pap smear test and with vaccination, adhering to routine screening of the susceptible female population through periodic Pap smears even in developed countries has been unsatisfactory. And to say that in India the organized screening program and awareness of cervical cancer is less and this lies as a barrier for the women to be screened for cervical cancer when they are presenting to the hospital as a routine basis ${ }^{[5,6]}$.So, awareness is essential for its implementation. Hence the medical students must be aware of the consequences and seriousness of the disease. Since these students are going to be a future clinician and they are the information resources in providing health education regarding the prevention of disease and motivating the patients for screening for cancer cervix and suggesting HPV vaccination, [7,8,9]. Very meager studies had been done in this aspect for the undergraduate medical students .Hence the aim of the study is to assess the level 
of awareness and attitude towards the cervical cancer screening methods and its prophylactic vaccination against HPV virus among the undergraduate medical students.

\section{Materials and Methods}

Study Design: This cross sectional study was conducted by the Department of Pathology and Pharmacology at Sri Manakula Vinayagar Medical College and hospital ,Puducherry in south India from July to August 2017 .Data was collected from the participants using pre-tested, validated and self administered questionnaires.

Study Participants: This study was performed among 400 M.B.B.S undergraduate students from second year to final year students in a semester wise pattern. That is the second year students belongs to fifth semester. Third year students belongs to sixth and seventh semesters and the final year students belongs to eighth and ninth semesters.

Data Collection Tools: A questionnaire form comprising of 20 multiple choice questions which were framed by getting an expert opinion was used as the data collection tool .The questionaire consisting of the questions about socio-demographic characteristics of the students such as Age and Level of Study (Semester) , and knowledge and attitudes towards cervical cancer, pap smear and HPV vaccination and it was distributed to the medical students of various semesters who agreed to participate in the study .And the students were informed for not writing their names on the questionnaire.A total of 400 students who were volunteered and given consent to participate were included in the study.

Statistical Analysis: Data was analysed with the help of Statistical Package for Social Sciences Softer version 24.0 (SPSS 24.0). Dependent variable is fixed as Knowledge and Attitude. Demographic characteristics of study participants such as Age and Level of Study (Semester) were fixed as Independent variable. The data were expresssed as percentage. Knowledge and attitude was compared with the inter-semester group of students using chi square test. $\mathrm{p}<0.05$ was considered as statistically significant.

Ethical Aspects of the Study: All necessary institutional permits and ethical commitee approval were taken in order to perform the study.

\section{Result}

A total of 400 students gave voluntary consent and completed the questionnaire in the study. The age group range was 20- 21 years with a mean age of $19.91+1.90$ years.Male participants $(50.3 \%)$ were higher than female participants (49.7\%). Most of the participants were from second year $\left(5^{\text {th }}\right.$ semester $) 166(41.5 \%)$, followed by $7^{\text {th }}$ semester and $9^{\text {th }}$ semester $(26.5 \%),(25.8 \%)$ respectively with only very few participants in the $6^{\text {th }}$ semester $(5 \%)$ and $8^{\text {th }}$ semester $(1.3 \%)$ were shown in Table 1. Correct responses to the question and its semester wise comparison are demonstrated in Table $2 \& 3$. Based on the semester distribution significant differences were noted regarding the knowledge of of cervical cancer and pap smear (96.8\% ) (55\%) respectively and $(p=0.004)$ as per table $2 \& 3$. Fortunately $58 \%$ of the participants were aware that cervical cancer can be terminal illness. Overall $84.3 \%$ of the study subjects stated that none of their relatives or friends suffered from cervical cancer. However $7.8 \%$ population gave report that their friends or relatives had cervical cancer. Among the participants $83 \%$ knew the association between cervical cancer and infection $(p=0.000)$. As per the result $81.8 \%$ agreed that HPV could be sexually transmitted table 3 . The most important cause for cervical cancer was stated as Human Papilloma virus infection (94.3\%) compare to smoking (4.3\%) and alcoholism (1.5\%) table 3. Surprisingly 59.8\% study participants agreed that genital warts can cause cervical cancer table 2 . According to $56.5 \%$ of the students the commonest site of cancer cervix is ecto cervix. as per table 2. Smoking was considered as precipitating factor by $52.5 \%$ of the participants. $49.8 \%$ think that use of contraceptives would be the risk factor for cervical cancer. However $50.2 \%$ of the participants were not having clear idea about correlation between contraceptives and cervical cancer. $91.5 \%$ and $54.8 \%$ have agreed that they have heard about pap smear and it is the diagnostic tool of cervical cancer respectively and $80.3 \%$ identified the full name of pap test as papanicolaou it was statistically significant $(p=0.000) 57.5 \%$ opined that they would observe abnormal epithelial cells as well as normal cells in pap smear whereas $39.3 \%$ and $3.3 \%$ of the study participants stated that they identify abnormal epithelial cells and normal cells respectively under pap smear. To our surprise $58.5 \%$ gave correct answer regarding strains of HPV. 55\% stated that they had heard about vaccination against cervical cancer as per table 2 . Unfortunately $93 \%$ of our participants had not been vaccinated so far. According to 55.8.\% of study participants pregnant women should not be vaccinated. $79.3 \%$ concluded that HPV vaccination was safe and effective shown in table $3.65 \%$ of the population identified $0.5 \mathrm{ml} \mathrm{IM}$ as the correct dose and route of HPV vaccination.

Based on the correct mean scores $5^{\text {th }}$ semester showed significant $(p=0.000)$ responses when compared with $6^{\text {th }}, 8^{\text {th }}$ and $9^{\text {th }}$ semesters in the knowledge of cervical cancer and HPV. The attitude towards the HPV vaccination also highly significant in $5^{\text {th }}$ semester students than $9^{\text {th }}$ semesters.

The study population based on the level of correct knowledge in (\%) observed that most of the participants had adequate knowledge but the comparison between the 
semesters showed significant difference for attitude scores where as no differences were seen based on knowledge in gender wise distribution. Correlation by Pearson Chi square coefficient showed significant positive correlation between all the knowledge and attitude scores i.e cervical cancer ,pap smear screening and HPV vaccination. Awareness.

Table 1: Demographic data of the participants.

\begin{tabular}{|c|c|}
\hline DEMOGRAPHY FACTOR & $\mathbf{n}(\%)$ \\
\hline Gender distribution & $201(50.3 \%)$ \\
Male & $199(49.8 \%)$ \\
\hline Female & $108(27.0 \%)$ \\
19 years & $136(34.0 \%)$ \\
20 years & $133(33.3 \%)$ \\
21 years & $19(4.8 \%)$ \\
22 years & $1(0.3 \%)$ \\
23 years & $2(0.5 \%)$ \\
24 years & $1(0.3 \%)$ \\
25 years & $166(41.5)$ \\
Sth & $20(5.0 \%)$ \\
6th & $106(26.5)$ \\
7th & $5(1.3 \%)$ \\
8th & $103(25.8 \%)$ \\
\hline
\end{tabular}

Table 2: Total number of correct responses (N\%)and comparison of correct responses between the semesters regarding knowledge about cervical cancer \& screening procedure.

\begin{tabular}{|c|c|c|c|c|c|c|c|}
\hline Questions & $\begin{array}{c}\text { Correct } \\
\text { response } n(\%)\end{array}$ & $\begin{array}{c}5^{\text {th }} \text { semester } \\
(\%)\end{array}$ & $\begin{array}{c}6^{\text {th }} \text { semester } \\
(\%)\end{array}$ & $\begin{array}{c}7^{\text {th }} \text { semester } \\
(\%)\end{array}$ & $\begin{array}{c}8^{\text {th }} \text { semester } \\
(\%) I\end{array}$ & $\begin{array}{c}9^{\text {th }} \text { semester } \\
(\%)\end{array}$ & $P$ value \\
\hline $\begin{array}{l}\text { Heard about } \\
\text { cervical cancer }\end{array}$ & $387(96.8 \%)$ & $40.8 \%$ & $4.6 \%$ & $27.3 \%$ & $1.2 \%$ & $25.8 \%$ & 0.335 \\
\hline $\begin{array}{l}\text { It is a terminal } \\
\text { illness }\end{array}$ & $232(58.0 \%)$ & $34.9 \%$ & $5.6 \%$ & $30.2 \%$ & $2.2 \%$ & $27.2 \%$ & $0.004^{*}$ \\
\hline $\begin{array}{l}\text { Ectocervix is the } \\
\text { common site }\end{array}$ & $226(56.5 \%)$ & $39.3 \%$ & $5.7 \%$ & $27.8 \%$ & $1.7 \%$ & $25.2 \%$ & 0.609 \\
\hline $\begin{array}{l}\text { Causative strain } \\
\text { of HPV }\end{array}$ & $234(58.5 \% \%)$ & $35.4 \%$ & $5.9 \%$ & $28.6 \%$ & $1.7 \%$ & $28.2 \%$ & 0.075 \\
\hline $\begin{array}{l}\text { Genital warts } \\
\text { cause cancer } \\
\text { cervix }\end{array}$ & $161(40.3)$ & $42.2 \%$ & $4.9 \%$ & $22.3 \%$ & $1.8 \%$ & $28.5 \%$ & 0.490 \\
\hline $\begin{array}{l}\text { Is it associated } \\
\text { with infections }\end{array}$ & $332(83.0 \%)$ & $41.5 \%$ & $3.6 \%$ & $29.8 \%$ & $1.2 \%$ & $23.7 \%$ & $0.000^{*}$ \\
\hline $\begin{array}{l}\text { Do any relatives } \\
\text { or friends suffer }\end{array}$ & $31(7.8 \%)$ & $12.9 \%$ & $9.6 \%$ & $16.1 \%$ & $0 \%$ & $61.2 \%$ & $0.000^{*}$ \\
\hline $\begin{array}{l}\text { Heard about pap } \\
\text { cytology }\end{array}$ & $366(91.5 \%)$ & $38.7 \%$ & $5.1 \%$ & $27.8 \%$ & $1.3 \%$ & $26.7 \%$ & $0.011^{*}$ \\
\hline $\begin{array}{l}\text { Full name of Pap } \\
\text { test }\end{array}$ & $321(80.3 \%)$ & $37.3 \%$ & $4.3 \%$ & $26.4 \%$ & $1.5 \%$ & $30.2 \%$ & $0.000^{*}$ \\
\hline $\begin{array}{l}\text { Observation in } \\
\text { pap smear }\end{array}$ & $230(57.5 \%)$ & $43 \%$ & $1.3 \%$ & $31.3 \%$ & $1.7 \%$ & $22.6 \%$ & $0.000^{*}$ \\
\hline
\end{tabular}


Table 3: Comparison of correct responses between the semesters regarding attitude about vaccination.

\begin{tabular}{|c|c|c|c|c|c|c|c|}
\hline Question & \begin{tabular}{|c|} 
Correct \\
response $\mathrm{n}(\%)$
\end{tabular} & $\begin{array}{c}5^{\text {th }} \text { semester } \\
\%\end{array}$ & $\begin{array}{c}6^{\text {th }} \text { semester } \\
\%\end{array}$ & $\begin{array}{c}7^{\text {th }} \text { semester } \\
\%\end{array}$ & $\begin{array}{c}8^{\text {th }} \text { semester } \\
\%\end{array}$ & $\begin{array}{c}9^{\text {th }} \text { semester } \\
\%\end{array}$ & $\stackrel{P}{\text { value }}$ \\
\hline $\begin{array}{l}\text { Smoking precipitate } \\
\text { cervical cancer }\end{array}$ & $210(52.5 \%)$ & $36.1 \%$ & $4.7 \%$ & $34.2 \%$ & $1.4 \%$ & $23.3 \%$ & $0.000^{*}$ \\
\hline $\begin{array}{l}\text { Use of Contraceptive is } \\
\text { a risk factor }\end{array}$ & $199(49.8 \%)$ & $50.25 \%$ & $3.8 \%$ & $27.6 \%$ & $1.5 \%$ & $16.5 \%$ & $0.000^{*}$ \\
\hline $\begin{array}{l}\text { Is this test gives } 100 \% \\
\text { sensitivity }\end{array}$ & $219(54.8 \%)$ & $40.2 \%$ & $3.1 \%$ & $36.9 \%$ & $1.8 \%$ & $17.8 \%$ & $0.000^{*}$ \\
\hline $\begin{array}{l}\text { Have you ever been } \\
\text { vaccinated }\end{array}$ & $28(7.0 \%)$ & $71.4 \%$ & $0 \%$ & $21.4 \%$ & $0 \%$ & $7.14 \%$ & $0.013^{*}$ \\
\hline $\begin{array}{l}\text { Should pregnant women } \\
\text { Can get vaccine }\end{array}$ & $223(55.8 \%)$ & $34.9 \%$ & $5.8 \%$ & $19.73 \%$ & $2.24 \%$ & $37.2 \%$ & $0.009^{*}$ \\
\hline $\begin{array}{l}\text { Is the vaccine safe and } \\
\text { effective }\end{array}$ & $317(79.3 \%)$ & $41.6 \%$ & $1.2 \%$ & $29.33 \%$ & $1.57 \%$ & $26.18 \%$ & $0.000^{*}$ \\
\hline $\begin{array}{l}\text { HPV transmitted } \\
\text { sexually }\end{array}$ & $327(81.8 \%)$ & $34.8 \%$ & $5.81 \%$ & $30.2 \%$ & $1.5 \%$ & $28.2 \%$ & $0.000^{*}$ \\
\hline $\begin{array}{l}\text { Important cause for } \\
\text { cervical cancer }\end{array}$ & $377(94.3 \%)$ & $39.25 \%$ & $5 \%$ & $27.5 \%$ & $1.32 \%$ & $26.7 \%$ & $0.034^{*}$ \\
\hline Heard about vaccination & $220(55 \%)$ & $24.5 \%$ & $3.1 \%$ & $31.8 \%$ & $2.2 \%$ & $38.1 \%$ & $0.000^{*}$ \\
\hline $\begin{array}{l}\text { Route and Dose of } \\
\text { administration }\end{array}$ & $260(65.0 \%)$ & $35.7 \%$ & $5.7 \%$ & $29.2 \%$ & $1.9 \%$ & $27.3 \%$ & 0.90 \\
\hline
\end{tabular}

\section{Discussion}

Knowledge and attitude of the effect of human papilloma virus and its preventive measures is very important in preventing the cervical cancer .Early screening prevents upto $80 \%$ of the invasive cancer cases .But lack of education and cultural patterns have been known as major reasons for low screening prevalence in many developing countries ${ }^{[7]}$. Awareness plays a major role in improvising the preventive methods. Hence this current study carried out with the aim of assessing the knowledge, attitude and practice towards the cervical cancer and HPV among the undergraduate medical students in a medical college in south India . It will provide a useful information that might help to provide a public health education regarding pap smear, HPV vaccine and prevention of cervical cancer.

In this current study the percentage of male participants was found to be more (50.3\%)when compared to female $(49.7 \%)$ and it may vary between the studies .A study conducted by swarnapriya et al ${ }^{[6]}$ found that female preponderance and it is dissimilar from the current study.

The percentage of heard about cervical cancer was $96.8 \%$ and it was expressed as percentage and it was more in female participants and was concurrent with a study done by swarnapriya et al ${ }^{\left[{ }^{6}\right.}$. However their knowedge was lower than that observed in a study among female health workers in a teaching hospital in northern Nigeria where $98.6 \%$ of female health workers had good knowledge about cervical cancer ${ }^{[8]}$. But from some studies like Hoque et al ${ }^{[9]}$ the percentage was lower.

There are so many risk factors for carcinoma cervix like early menarche,smoking, nulliparity and multiple sexual partners and the most common cause among this is sexual transmission of HPV infection in this study $81.75 \%$ of the students identified the HPV risk by sexual transmission and $18.75 \%$ did not aware of that , a study done by Borlu et al ${ }^{[10]}$ found only $36.5 \%$ of the participants knew that cervical cancer is due to sexual transmission of HPV and their results were not identical from our current study and it is the most striking features should be known by the students .In contrast to our study findings were same as in the Nigerian study done by Ugwu et al ${ }^{[11]}$ they also observed that more than $50 \%$ of the students were aware of HPV risk.

Pap smear is the non invasive screening technique and it aids a rapid diagnosis for early management and further preventive measures and it is a appropriate screening method and from our study $94.4 \%$ of the participants have adequate knowledge and aware of that and it was concurrent with the studies done by Pandey et al ${ }^{[12]} \& \mathrm{Al}-$ Dubai et al ${ }^{[13]}$ and not concurrent with Chamaraja et al ${ }^{[14]}$ and he found that all the respondandants have heard about pap smear. 
HPV vaccination is very useful in preventing cervical cancer and the awareness and hearing about vaccination was not adequate in few studies. In this about HPV vaccination against the cervical cancer $82.4 \%$ of the participants has good knowledge, $49.75 \%$ opted that contraception protects against HPV but it is not concurrent with a study done by Borlu et a ${ }^{[10]}$ and Ugwu et $\mathrm{al}^{[11]}$ and it was concurrent with Pandey et a ${ }^{[12]}$.Also most of the participants in this study did not aware the dosage and schedule of the HPV vaccine and is similar to the study observations in New Delhi ${ }^{[15] \text {. }}$

In the present study the female students (58.7\%)had more knowledge regarding HPV vaccine than male students(51.2\%) and it is concurrent with the Pitts et al ${ }^{l}$ 16 ] Many students from lower class level had adequate knowledge of HPV and vaccination.

Among the students $7 \%$ only vaccinated against HPV and it was concurrent with the study of Tung et al ${ }^{[1]}$ and it was not similar with a study done by Hoque et a ${ }^{[9]}$. Contrast to other literatures the percentage of students wants to be vaccinated for HPV was very low at our study.

Current study found that significant higher knowledge about cervical cancer ,pap smear and HPV vaccination were seen in fifth semester[second year ]students compared to high semester students and it was dissimilar from the study of Borlu et al ${ }^{[10]}$. A malaysian study conducted among university female students reported that knowledge regarding HPV ,HPV vaccination ,cervical screening and cervical cancer risk factors was remarkably poor .A recent review study concluded that awareness of both cervical cancer and HPV vaccination is low in women ${ }^{[17]}$.

In comparison with previous studies, the present study knowledge of risk factors of cervical cancer significantly identified the willingness to accept HPV vaccination. this observation is contrast with other studies .

Inspite of proven efficacy of HPV Vaccine, the vaccination is very poor in india this is mainly due to lack of adequate knowledge and non availability of vaccine are the major factors for poor acceptance of vaccination ${ }^{[7]} \cdot \mathrm{In}$ many Europian countries $80 \%$ of the people has been vaccinated but in developing countries vaccination rates are disappointed. Our study observed a necessity for increased awareness of HPV and its vaccination to increase the vaccine acceptance rates.

\section{Conclusion}

In conclusion, the knowledge about cervical cancer, HPV , pap smear screening and preventive measures against it among the medical students were high. Many of them had positive attitudes towards HPV vaccination but only very few students are already vaccinated. So some training sessions should be planned to improve their knowledge and educate about the pap smear screening and vaccination among the undergraduate medical students of various semesters. Since these students are going to be a future clinician and they are the information resources in providing health education regarding the prevention of disease and motivating the patients for screening for cancer cervix and suggesting HPV vaccination This may reduce the prevalence of cervical cancer among the women in south India.

\section{Acknowledgement}

We thank to our director for giving permission to conduct the study. And also thank those students who voluntarily participated in this study.

\section{Reference}

1. Tung ILY, Dorothy A, et al . Attitudes, Knowledge and factors associated with Human papillomavirus(HPV) Vaccine Uptake in Adolescent girls and young women in Victoria, Australia. PLoS ONE 11(8):e0161846.

2. Parkin DM, Bray F, Ferlay J, Pisani P. Global cancer statistics, 2002. CA Cancer J Clin. 2005;55: 74-108.

3. Karthhigeyan $\mathrm{K}$ et al. Cervical cancer in india and HPV Vaccination. Indian J Med Paediatr Oncol. 2012 Jan-Mar ;33(1):7-12.

4. Francis SA, Nelson J, Liverpool J, Soogun S, MofammereN, Thorpe RJ Jr. Examining attitudes and knowledge about HPV and cervical cancer risk among female clinic attendees in Johannesburg: South Africa. Vaccine 2010; 28: 8026-8032.

5. Dhodapkar SB, Chauhan RC. Knowledge and awareness of cervical cancer and its prevention among nursing staff of a tertiary care teaching institute in South India. Int J ReprodContraceptObstet Gynecol. 2014; 3(4): 1056-1060.

6. Swarnapriya K, Kavitha D. Knwledge ,attitude and practices regarding HPV vaccination among medical and paramedical students, India a cross sectional study. Asian Pac J Cancer Prev ,2015 ,16(18),8473-8477.

7. Ganju AS, Neha G, Vijay B. Assessment of knowledge and attitude of medical and nursing students towards screening for cervical carcinoma and HPV Vaccination in a tertiary care teaching hospital. Int J Community Med Public Health,2017 Nov;4(11):4186-4193.

8. Makwe CC, Anorlu RI, Odeyemi KA. Human papillomavirus (HPV) infection and vaccines: knowledge, attitude and perception among female students at the University of Lagos, Lagos, Nigeria. J Epidemiol Glob Health 2012, 2, 199-206.

9. Hoque ME, Shanaz G ,et al. Human Papillomavirus Vaccination acceptability among female university students in south Africa. Asian Pac J Cancer Prev 2013, 14(8),48654869 . 
10. Borlu A, Osman G. Knowledge and attitudes of medical and non medical Turkish university students about cervical cancer and HPV vaccination. Asian Pac J Cancer Prev 2016,vol $17,299$.

11. Ugwu EO, Obi SN, Ezechukwu PC , Okafor II, Ugwu AO. Acceptability of human papillomavirus vaccine and cervical cancer screening among female health -care workers in Enugu, Southeast Nigeria. Niger J Clin Pract 2013;16(2):249-52.

12. Pandey D, Vanya V, Bhagat S. Awareness and attitude towards human papillomavirus (HPV) vaccine among medical students in a premier medical school in India. PLoS ONE $2012 ; 7(7):$ e40619.

13. Al-Dubai SA, Alshagga MA, Al-Naggar RA, et al . Knowledge, attitudes and barriers for human papilloma virus (HPV)vaccines among Malaysian women. Asian Pac J Cancer Prev 2010;11,887-92.

14. Chamaraja T, Surekha S. Knowledge, Attitude and Practice of the pap smear as a screening procedure among nurses in a tertiary hospital in north eastern India. Asian Pac J Cancer Prev, 2013, 14 ,849.

15. Mehta S, Rajaram S, Goel N. Awareness about human papillomavirus and its vaccine among medical students . Indian J Community Med 2013;38(2):92-4.

16. Pitts MK, Heywood W, Ryall R, Smith AM, et al. Knowledge of human papillomavirus (HPV) and the HPV vaccine in a national sample of Australian men and women. Sex Health.2010;7:299-303.

17. Wong LP, Sam IC. Ethnically diverse female university students" knowledge and attitudes towards human papillomavirus (HPV0, HPV vaccination and cervical cancer. Eur J Obstet Gynecol Reprod Biol,148,90-5.

18. Martin CS. Wong . Knowledge, Attitude, Practice and Barriers on Vaccination against Human Papillomavirus Infection: A Cross-Sectional Study among Primary Care Physicians in Hong Kong.PLoS One. 2013; 8(8): e71827.

19. Rambout L, Tashkandi M, Hopkins L, Tricco AC. Self-reported barriers and facilitators to preventive human papillomavirus vaccination among adolescent girls and young women: a systematic review. Prev Med. 2014;58:22-32.

20. Nisreen A, Farzana R. Knowledge and attitude about cervical screening and HPV vaccine among female medical students of Taif. university. Int.J.Curr.Res.Aca.Rev; 2015,3(8):106-112.

21. Riedesel JM1, Rosenthal SL, Zimet GD, Bernstein DI, Huang B, Lan D, Kahn JA. Attitudes about human papillomavirus vaccine among family physicians. J Pediatr Adolesc Gynecol. 2005 Dec;18(6):391-2005 Dec;18(6):391-8

22. Vasconcelos CTM, Pinheiro AKB, Castelo ARP, Costa LQ, Oliveira RG.Knowledge, Attitude and Practice Related to the Pap Smear Test Among Users of a Primary Health Unit. Rev. Latino-Am. Enfermagem 2011 Jan-Feb;19(1):97-105.

23. Macartney KK, Chiu C, Georgousakis M, Brotherton JM. Safety of human papillomavirus vaccines: a review. Drug Saf. 2013;36(6):393-412.

24. Makwe CC, Anorlu RI, Odeyemi KA.Human papillomavirus (HPV) infection and vaccines: knowledge, attitude and perception among female students at the University of Lagos, Lagos, Nigeria. J Epidemiol Glob Health 2012, 2, 199-206.

*Corresponding author:

Dr Nitya Selvaraj, Sri Manakula Vinyagar Medical College and Hospital, Kalitheerthalkuppam, Madagadipet, Puducherry, 605107, India

Phone: +919787679839

Email: drnityapharm@gmail.com

Financial or other Competing Interests: None. 